\title{
Proactive risk mitigation strategies and building strategic resilience in the food supply chain: a review
}

\author{
Afifa, Y.N. and "Santoso, I. \\ Department of Agroindustrial Technology, Faculty of Agricultural Technology, Brawijaya University, \\ Malang, East Java, Indonesia
}

\author{
Article history: \\ Received: 3 March 2021 \\ Received in revised form: 14 \\ April 2021 \\ Accepted: 17 June 2021 \\ Available Online: 6 March \\ 2022
}

Keywords:

Risk mitigation,

Food Supply Chain,

Resilience,

Strategy,

Proactive

\section{DOI:}

https://doi.org/10.26656/fr.2017.6(2).257

\begin{abstract}
Risk management is very important in supporting business sustainability. The choice of risk mitigation strategy is very crucial. An alternative strategy that is considered very effective in managing risk is a proactive strategy. This review was aimed to find out the strategy of risk mitigation proactive in general supply chain, resilience strategy in the food supply chain, and the relationship between proactive risk mitigation strategies and supply chain resilience strategies. Supply chain resilience is the focal point of management to be task-oriented towards improvement, determination and continuity. Therefore, the mitigation process is an inseparable part of building supply chain resilience. The role of risk management provides important value for the company, there are four elements used to build or develop supply chain resilience, including supply chain (re-) engineering, collaboration, agility and risk awareness. Supply chain resilience strategies are reviewed on $3 \mathrm{R}$ aspects, which are ready, response and recover.
\end{abstract}

\section{Introduction}

Risks are classified into those that can be avoided and those that cannot be avoided. Risks are categorized into two main classes based on priority levels of risks that can be avoided and un-avoided. Thus, risk mitigation can be built and also mitigation plans (Shahzad, 2010; Choirun et al., 2020). Resilience strategies are used to deal with market and environmental shocks in maintaining the food supply chain (Folke, 2006). Factors affecting supply chain resilience are internal and external factors, internally occurring in the supply chain while external outside the control of the organizations involved (Christopher and Peck, 2004). Factors affecting food supply chain resilience that affect the resilience of such as natural disasters, technological failures, infectious diseases, terrorism and food security (Leat and Revoredo, 2013).

Food supply chain resilience is determined by efficiency, innovation, resource management, responsive organization and supporting product quality. In order for the food supply chain to survive the structural aspects are needed and managed effectively to increase expertise or supply chain resilience (Manning and Soon, 2016). Supply chain resilience focus on improvement, determination and continuity (Morecroft et al., 2012). The mitigation process is an inseparable part of building

*Corresponding author.

Email: imamsantoso@ub.ac.id food supply chain resilience. The role of risk management can increase understanding of the relationship between proactive mitigation strategies and supply chain management (Saglam et al., 2020). New strategies are needed to solve the problem. Risk mitigation strategies are expected to reduce risk, even used as a better solution to solve the problem (Rahmatin, 2018). The purpose of this study is to find out (1) the strategy of risk mitigation proactive in the general supply chain, (2) resilience strategy in the food supply chain, (3) the relationship between proactive risk mitigation strategies and supply chain resilience strategies. The topics discussed in eight parts, including introduction, risk mitigation, supply chain risk mitigation strategies, proactive risk mitigation, strategic and operational resilience, supply chain resilience, supply chain resilience strategies, future risk mitigation in the supply chain and conclusions.

\section{Risk mitigation}

Mitigation is an action to reduce or minimize the potential negative impact of a problem (Chan, 2003). Supply chain risk is categorized into 3 main risks such as supply risk, manufacturing process risk and shipping risk (Sreedevi and Haritha, 2017). In reducing risk, observations of inventory, manufacturing and logistics are carried out (Vickery et al., 1999). Mitigation within a 
company is needed to determine whether risks can be corrected properly and correctly so that there is no risk of hindering company activities. It becomes the basis for strategic decisions and to build a model to evaluate supply chain risk mitigation options (Mensah, 2017). In risk mitigation, the role of partners is also important, partners must support risk mitigation strategies because they can improve the efficiency of the strategy and assist companies to apply risk mitigation strategy effectively (Kurniawan et al., 2017). A theoretical decision framework provides a quantitative decision support system for selecting risk mitigation strategies in the supply chain (Andre et al., 2018). The type of food supply chain flexibility that is appropriate to mitigate the risk that is the risk of the manufacturing process and shipping risk (Sreedevi and Haritha, 2017).

\section{Risk mitigation strategies}

A risk mitigation strategy is a standardization that is applied to reduce potential risks. Implementation of this strategy includes the participation of employees, both as controllers (executors) and as management (Santoso et $a l, 2018)$. There are two types of supply chain risk mitigation strategies, proactive and reactive (Ghadge, 2012). A proactive strategy is a prevention strategy before a risk occurs by taking appropriate action, whereas a reactive strategy is an action taken after a problem occurs, then taking steps to recover the uncertain conditions due to risk (Wieland and Wallenburg, 2013). In conditions of supply chain uncertainty, organizations can use either proactive or reactive strategies or both to deal with the situation. Mitigation strategies to deal with supply chain risks such as collaboration with major suppliers (Mikkola, 2006). Various supply chain risk mitigation strategies are practised by organizations including resilient strategy, lean strategy, agile strategy, flexible strategy. Of the various strategies described resilient and agile strategies can significantly improve supply chain performance (Wieland and Wallenburg, 2012).

\section{Proactive risk mitigation strategies}

Proactive and responsive risk mitigation strategies are important for handling supply chains, increasing responsiveness and enhancing company sustainability (Chopra, 2004). The supply chain must be proactive for strategic planning (Ivanov et al., 2014). Proactive risk mitigation strategies related to management/retailer development, supply chain contracts, product/process management, and supplier relations (Ghadge et al., 2012). Disruption of the supply of raw materials, the production process can cause problems, therefore need to develop strategies to minimize risk in the supply chain with the aim of avoiding things that endanger the company (Mustaniroh et al., 2017). It is expected that supply chain management can see the future that it can face and survive the challenges that will come. In the case of pasteurized milk production, Santoso et al. (2018) reported the risks in the production process caused by raw materials, the production process, human resources, and machinery and equipment. The proactive mitigation strategies that should be developed are standardization and supervision to control the quality of raw materials, production process, and final product.

\subsection{Supply chain resilience}

Supply chain resilience is the ability that enables the supply chain to rebuild the business and make the supply chain stronger than before (Christopher and Peck, 2004). Resilience has a broader meaning than supply chain risk control (Brusset and Teller, 2017). Members of the supply chain are responsible for maintaining their organization and discussing social relationships, as well as supply chain resilience (Gölgeci and Kuivalainen, 2019). Supply chain resilience will be enhanced by creating a culture of risk mitigation within the organization. Thus, the existence of a high-risk mitigation culture will increase the positive effect of a proactive risk mitigation strategy on the performance of the food supply chain (Christopher and Peck, 2004). Supply chain resilience shows the relationship between external capabilities, integration capabilities, improvement capabilities and resilience (Brusset and Teller, 2017).

\subsection{Supply chain response capacity}

The responsiveness of the supply chain has supported supply chain management, such as responsive manufacturing, responsive operations (Hallavo, 2015). The strength of a company to be responsive comes from the company's supply chain, as well as the members and collaborative efforts between the supply chain (Ayoub and Abdallah, 2019). To achieve a responsive supply chain, companies must have great coordination such as collaboration with suppliers, sharing information with customers or using sophisticated manufacturing technology (Roh et al, 2014). Effective implementation of integrated responsive supply chain strategies from inter-organizational resources, such as social-relational and integrated technology. Thus, a responsive supply chain is important so the supply chain can achieve a competitive advantage (Jahre and Fabbe, 2015; Nuryanto et al., 2020).

\subsection{Supply chain flexibility}

Supply chain flexibility is a reflection of an organization's ability to respond to an operational 
process that is effective and efficient against changes or constraints (Sezen, 2008). Proactive supply chains must be flexible and easily adapt to the needs of their partners and environmental conditions in the limit/minimum time (Stevenson and Spring, 2007). Flexibility is aimed at the organization and inventory in the overall supply chain. Flexibility creates supply chain resilience by increasing flexibility in urgent situations (Christopher and Holweg, 2011).

\section{Strategic and operational resilience}

Strategic resilience and operational resilience are the focus after improving supply chain systems. Resilience is the ability of organizations to overcome problems and improve the ability to change economic, physical, political and social situations for the better (Hamel, 2003). Strategic resilience is resilience used in maintaining supply chain systems to support company trends to going well (Hamel, 2003). Operational resilience and strategic resilience are distinguished by the focus of the recovery strategy, which is based after handling challenges or after being made improvements and based on resilience in dealing with challenges, making management more proactive (Välikangas and Romme, 2012). Management can reduce risk by having a contingency or recovery strategy (Mintzberg, 1978).

Strategic resilience needs to be clearly defined to accommodate from fluctuations in inventory unexpected (Hak et al., 2012). The company's goals are more specific, relevant and timely measurements are made. So that it can have a strategic impact and affect the performance of the food supply chain (Manning and Baines, 2004). Socio-economic supply chains (efficiency, responsiveness, and product quality) can be used at the strategic supply chain level or operational level (Bourlakis et al., 2014).

\section{Supply chain resilience}

Resilience is a proactive and holistic step to managing supply chains in improving strategies to consider risk, planning, resilience and disruption (Pettit et al., 2010). An important aspect of supply chain resilience is the capacity of the supply chain to deal with upheavals, disruptions, and unexpected events (Bhamra et al, 2011). Supply chains can survive in an unstable condition and produce products and services that are categorized as resilient (Blackhurst et al., 2011). In the resilience of the supply chain, companies are expected to be able to survive, adapt, and grow to solve changes and problems. Resilience has broader implications than controlling risk in the supply chain (Hendricks, 2005). Resilience in the supply chain is based that not all risks can be prevented (Jüttner and Maklan, 2011). The adaptive ability of the supply chain to prepare for unexpected events, respond and resolve problems at the level of control (Ponomarov and Holcomb, 2009). The concept of a resilient food supply chain from a systems perspective addresses four main capabilities to develop supply chain resilience (Christopher and Peck, 2004) as presented in Figure 1.

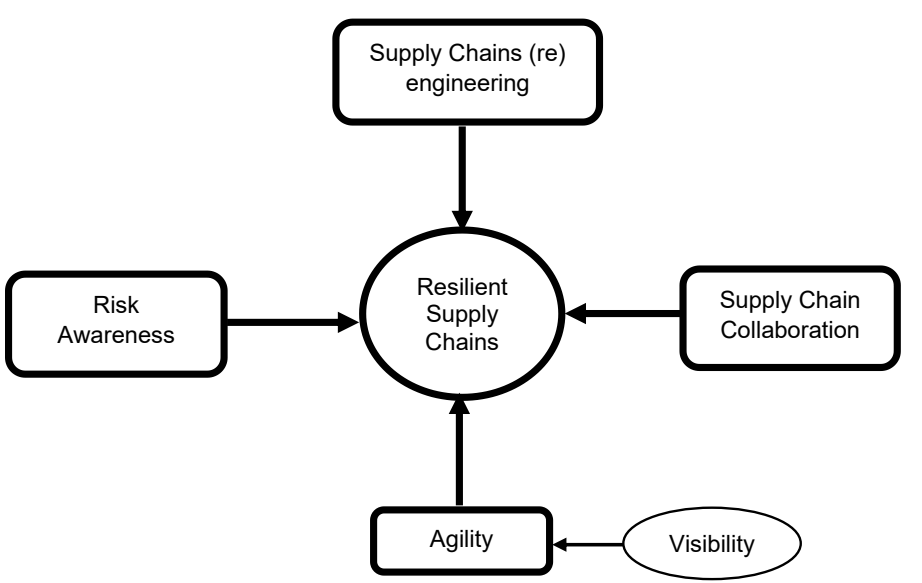

Figure 1. Supply Chain Endurance Aspects.

Source: Christopher and Peck (2004)

\subsection{Supply chain re-engineering}

Food supply chain re-engineering aims to overcome uncertainty with various aspects of the supply chain, including changes in customer needs and demands, information, and the influence of purchasing and ordering decisions (Radosevic et al., 2013). Supply chain resilience must be built before disruption and responsive preparation that is more efficient and effective (Ponomarov and Holcomb, 2009). A strong supply chain strategy will increase a company's ability to maintain operations in the event of a disruption (Tang, 2006). Mapping the supply chain network to direct and activate priority management planning is relevant for balancing operational efficiency with capacity needs (Sheffi and Rice, 2005). Effective handling of problems can be achieved through collaboration between different supply chain members (Blackhurst et al., 2011).

\subsection{Collaboration}

The basic principle of supply chain collaboration is information and application of knowledge throughout the supply chain increasing the visibility of operational reliability and efficiency and improving customer service (Faisal et al., 2006). Collaboration between organizations in integrated supply chains is needed to build supply chain resilience (Sheffi, 2001). Collaboration between supply chain members emphasizes how cooperation can support supply chain efficiency and provide strategic knowledge to improve food supply chain performance (Jüttner and Maklan, 2011). Collaboration across the entire supply chain can significantly help reduce risk. The basic principle of 
collaborative work in the supply chain is the exchange of information to reduce uncertainty. The main priority for risk reduction must be the creation of supply chain communication for information exchange between supply chain members (Ireland, 2002). Horizontal collaboration occurs between organizations that work at the same level, usually in partnership, or different functional departments. Collaboration is important both before and during the problem but also after the problem it would also be good to continue, with the aim of increasing the ability of the system to achieve the future (Sheffi, 2005).

\subsection{Agility}

Agility in the food supply chain has a positive side, its rapid increase in adapting to unexpected changes or in demand also in supply (Pettit et al., 2010). Resilience in the food supply chain requires agility, subjects in agility represent a role to continuously for the most appropriate response to changes, decisions and patterns in the business environment (Lin et al., 2006). Supply chain agility is expected to react quickly to changes in supply and demand are uncertain (Christopher and Peck, 2004). The flexibility of the ease of the coordination process allows organizations to overcome the level of problems in the environment and operations (Manuj and Mentzer, 2008). Visibility ensures trust in supply chains, prevention of overreaction, violations that occur and ineffective decisions in supply chain risk (Christopher and Lee, 2004). It is important to increase the visibility, speed and foundation needed in the food supply chain (Faisal et al., 2006).

\subsection{Risk awareness}

Risk awareness can be used for resilient supply chain planning and requires a supportive management role (Christopher and Peck, 2004). To realize a resilient supply chain, organizations need to develop appropriate management policies and actions to coordinate efforts in the supply chain network (Kleindorfer and Saad, 2005). The application of risk management or risk awareness enables the company to control the risks that will or are being experienced. Thus, risk mitigation or risk management needs to be done to reduce the risk that occurs (Wahyudin, 2016). Partners in the supply chain share common understanding and awareness in the process of operating systems (Faisal et al., 2006). Media is needed to learn, develop, and be better prepared for the future of the supply chain is the main thing of the supply chain resilience (Ponomarov and Holcomb, 2009). Some companies provide training to employees, suppliers/ retailers and customers about raising awareness of supply chain resilience (Blackhurst et al., 2011). Knowledge and understanding of the structure of the food supply chain is an important element in the security of the supply chain (Choi and Hong, 2002). Elements have resource sustainability often referred to as functional areas and are manifested in the supply chain process (Jüttner and Maklan, 2011). Considering the ability of management and the company needs to be done so, it can be operationalized and applied in practice if wants to advance understanding of supply chain sustainability (Bamberger and Pratt, 2010).

\section{Strategic resilience supply chain}

The strategy of resilience in the supply chain includes three-part, ready, response and recover regarding supply chain resilience. If supply chain resilience has been conceptualized, it requires the ability of the supply chain strategy to be ready to respond, restore and change the new order for the better (Tukamuhabwa et al., 2015). Within the framework through internal and external organizational considerations, the ability of the organization/individual where the food supply chain is ready, responding, and restoring conditions/circumstances supply chain relationships depend on the ability of each food supply chain organization to be efficient, flexible, responsive and meet customer specifications for the fulfilment of their products and services (Jüttner and Maklan, 2011). The framework must complement the indicators used as a process of activating the supply chain to create the value of the organization and increase their strategic and operational resilience for stakeholder approval (Faisal et al., 2006). Factors considered in supply chain resilience strategies are strategic leadership, value-based dynamics and the use of performance indicators in the context of external and internal influences at the executive, organizational and individual levels. Using the ready, response and recovery strategies to overcome internal and external risks and supply chain risk mitigation so it can be done as fully as possible (Rice and Caniato, 2003). Strategic resilience factors by level shown in Table 1 and strategic resilience factor to $3 \mathrm{R}$ shown in Table 2.

\section{Future research}

The future of the agricultural sector is the creation of a strong and sustainable agricultural system. The uncertainty that arises in the supply chain the core is management. Risk mitigation is used to deal with sources of bad uncertainty and negative impacts on safety, quality, quantity and products not targeted in the food supply chain system. It is expected in subsequent studies, risk mitigation strategies sharing factors or different points of view of the supply chain can be investigated. In supply chain flexibility and SCRM 
Table 1. Strategic Resilience Factors by Level

\begin{tabular}{|c|c|c|c|}
\hline Factor & Executive level & Organizational Level & Individual level \\
\hline Decision-making & 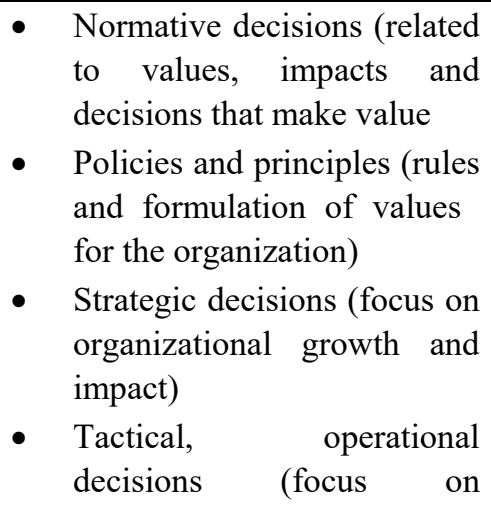 & $\begin{array}{l}\text { - } \begin{array}{l}\text { Normative decisions } \\
\text { (cultural, internal values) }\end{array} \\
\text { - } \text { Policies and principles (in) } \\
\text { - } \\
\text { Strategic decisions (internal } \\
\text { focus that impacts the } \\
\text { organization } \\
\text { - Tactical, operational } \\
\text { decisions (focus on } \\
\text { efficiency and cost) }\end{array}$ & $\begin{array}{l}\text { - } \begin{array}{l}\text { Normative decisions } \\
\text { (cultural, internal values) }\end{array} \\
\text { - } \\
\text { Policies and principles (in) } \\
\text { Strategic decisions (internal } \\
\text { focus that has an } \\
\text { organizational impact) } \\
\text { Tactical operational } \\
\text { decisions (focus on personal } \\
\text { efficiency) }\end{array}$ \\
\hline $\begin{array}{c}\text { Performance } \\
\text { Indicator }\end{array}$ & 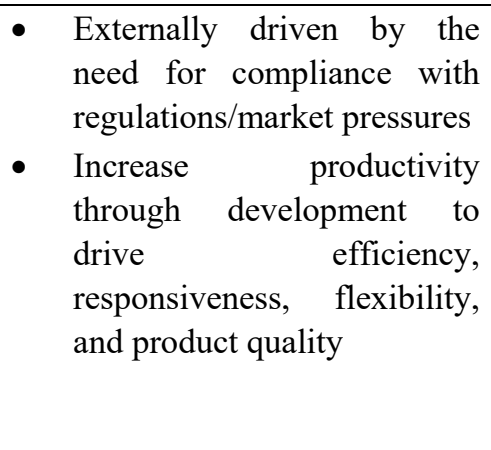 & $\begin{array}{l}\text { - Internal driven from the } \\
\text { need for compliance with } \\
\text { market pressure or } \\
\text { regulations } \\
\text { - Increase operational } \\
\text { productivity through } \\
\text { development to drive } \\
\text { efficiency, responsiveness, } \\
\text { flexibility, and product } \\
\text { quality }\end{array}$ & 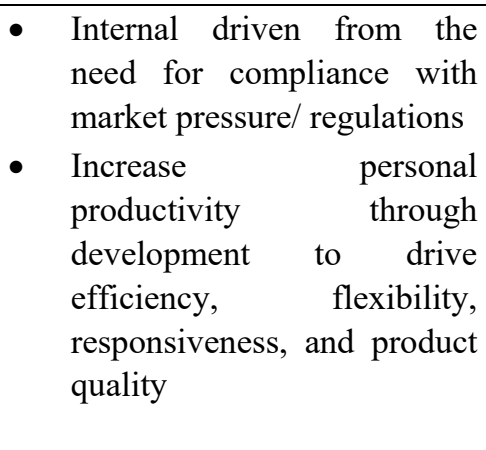 \\
\hline
\end{tabular}

Sources, Muthuri et al. (2006), Delmas et al. (2011), Caiazza et al. (2014), Caiazza (2015)

Table 2. Strategic Resilience Factor to $3 \mathrm{R}$

\begin{tabular}{|c|c|c|c|}
\hline $\begin{array}{c}\text { Strategic Resilience } \\
\text { Factors }\end{array}$ & Ready & Respond & Recover \\
\hline Value dynamics & $\begin{array}{l}\text { Following new developments, } \\
\text { ready for inspection and } \\
\text { auditing, developing alternatives } \\
\text { to assess supply chains } \\
\text { (Ponomarov and Holcomb, } \\
2009 \text { ) }\end{array}$ & $\begin{array}{l}\text { Quick and appropriate responses } \\
\text { to complaints. Fast-tracking } \\
\text { when supply chain shocks occur } \\
\text { (Manning, 2016) }\end{array}$ & $\begin{array}{l}\text { Response to ensure rapid } \\
\text { recovery and continuous } \\
\text { improvement (Elliott et al., } \\
2002)\end{array}$ \\
\hline Strategic leadership & $\begin{array}{l}\text { Associated with making } \\
\text { decisions about the vision and } \\
\text { mission of the organization, } \\
\text { ensuring compliance with the } \\
\text { changing environment and } \\
\text { consumer needs. Reviewing the } \\
\text { strategic goals and } \\
\text { organizational goals (Manning, } \\
\text { 2016) }\end{array}$ & $\begin{array}{l}\text { Associated with top } \\
\text { management decision making to } \\
\text { support the organization in } \\
\text { implementing decisions. } \\
\text { Realigning strategic and } \\
\text { organizational goals } \\
\text { (Välikangas, 2012) }\end{array}$ & $\begin{array}{l}\text { Continuous improvement, } \\
\text { responsiveness to ensure rapid } \\
\text { recovery. Reaffirm strategic and } \\
\text { operational objectives and } \\
\text { develop goals if necessary. } \\
\text { (Mintzberg, 1978) }\end{array}$ \\
\hline
\end{tabular}

(Supply Chain Risk Management) performance, there is an environmental uncertainty response, then environmental uncertainty can be examined in future research in order to obtain the boundary classification of supply chain environment uncertainty. In future research, can be use method to take the link between the impact of technology or existing methods and solutions to improve efficiency, sustainability, flexibility, agility, and resilience of the entire supply chain from farmers to end customers.

\section{Conclusion}

Risks can be categorized into two main classes based on the priority level of risks that can be avoided and un- avoided. Therefore, mitigation or specific risk avoidance plans can be built. Supply chain resilience is a management focal point to be oriented to the task of improvement, persistence and continuity of performance. Hence, the mitigation process is an inseparable part of building supply chain resilience. Because of the challenges of global competition, the role of risk management provides important value to the company. There are four elements used to build or develop supply chain resilience, including supply chain (re-engineering), collaboration, agility and risk awareness. Supply chain resilience strategies are reviewed on several aspects including $3 \mathrm{R}$, such as ready, respond and recover. 


\section{Conflict of interest}

The authors declare no conflict of interest.

\section{Acknowledgement}

We would like to thank for Rector of Universitas Brawijaya who has provided a research grant via the Professor Grant Scheme to fully support for writing this manuscript as part of the professor grant.

\section{References}

Andre, S., Maximiliano, U. and Jan, C.F. (2018). A Stochastic Program to Evaluate Disruption Mitigation Investment in The Supply Chain. European Journal of Operation Research, 274(2), 516-530. https://doi.org/10.1016/j.ejor.2018.10.005

Ayoub, H. and Abdallah, A. (2019). The effect of supply chain agility on export performance, the mediating roles of supply chain responsiveness and innovation. Journal of Manufacturing Technology Management, 30(5), 821-839. https://doi.org/10.1108/JMTM-082018-0229

Bamberger, P. and Pratt, M. (2010). Moving forward by looking back, reclaiming unconventional research contexts and samples in organizational scholarships. Academy of Management Journal, 53(4), 665-671. https://doi.org/10.5465/amj.2010.52814357

Bhamra, R., Dani, S. and Burnard K. (2011). Resilience, the concept, a literature review and future direction. International Journal Production Research, 49(18), 5375-5393. https:// doi.org/10.1080/00207543.2011.563826

Blackhurst, J., Dunn, K. and Craighead, C. (2011). An empirically derived framework of global supply resilience. Journal Business Logistics, 32(4), 374 391. https://doi.org/10.1111/j.00000000.2011.01032.x

Bourlakis, M., Maglaras, G., Gallear, D. and Fotopoulos, C. (2014). Examining sustainability performance in the supply chain, the case of the Greek dairy sector. Industrial Marketing Management, 43(1), 56-66. https://doi.org/10.1016/j.indmarman.2013.08.002

Brusset, X. and Teller, C. (2017). Supply chain capabilities, risks, and resilience. International Journal of Production Economics, 184, 59-68. https://doi.org/10.1016/j.ijpe.2016.09.008

Caiazza, R. and Volpe, T. (2015). Interaction despite diversity, is it possible? Journal of Management Development, 34(6), 743-750. https:// doi.org/10.1108/JMD-10-2013-0131

Caiazza, R., Volpe, T. and Audretsch, D.B. (2014). Innovation in agro-food systems, policies, actors and activities. Journal of Enterprising Communities, People and Places in the Global Economy, 8(3), 180 -187. https://doi.org/10.1108/JEC-06-2014-0009

Chan, F.T. (2003). Performance Measurement in a Supply Chain. The International Journal of Advanced Manufacturing Technology, 21(7), 534-54. https://doi.org/10.1007/s001700300063

Choi, T.Y. and Hong, Y. (2002). Unveiling the structure of supply networks, case studies in Honda, Acura, and Daimler Chrysler. Journal of Operations Management, 20(5), 469-493. https:// doi.org/10.1016/S0272-6963(02)00025-6

Choirun, A., Santoso, I. and Astuti, R. (2020). Sustainability risk management in the agri-food supply chain, literature review. IOP Conference Series, Earth and Environmental Science, 475(1), 012050 . https://doi.org/10.1088/1755$1315 / 475 / 1 / 012050$

Chopra, S. and Sodhi, M.S. (2004). Managing risk to avoid supply chain breakdown. Sloan Management Review, 46(1), 53-62.

Christopher, M. and Holweg M. (2011). Supply Chain 2.0, managing supply chains in the era of turbulence. International Journal Physic Distribution Logistics Management, 41(1), 63-82. https:// doi.org/10.1108/09600031111101439

Christopher, M. and Lee, H. (2004). Mitigating supply chain risk through improved confidence. International Journal of Physical Distribution and Logistics Management, 34(5), 388-396. https:// doi.org/10.1108/09600030410545436

Christopher, M. and Peck, H. (2004). Building The Resilient Supply Chain. International Journal of Logistics Management, 15(2) 1-13. https:// doi.org/10.1108/09574090410700275

Delmas, M. and Burbano, V.C. (2011). The drivers of greenwashing. California Management Review, 54 (1), 64-87. https://doi.org/10.1525/cmr.2011.54.1.64

Elliott, D., Swartz, E. and Herbane, B. (Eds.). (2002). Business Continuity Management. A Crisis Management Approach. London: Routledge. https:// doi.org/10.4324/9780203996904

Faisal, M.N., Banwet, D.K. and Shankar, R. (2006). Supply chain risk mitigation, modeling the enablers. Business Process Management, 12(4), 535-552. https://doi.org/10.1108/14637150610678113

Folke, C. (2006). Resilience, The Emergence of a Perspective for Social-Ecological Systems Analyzes. Global Environmental Change, 16(1), 253-267. https://doi.org/10.1016/j.gloenvcha.2006.04.002

Ghadge, A., Dani, S. and Kalawsky, R. (2012). Supply Chain Risk Management, Present and Future Scope. 
The International Journal of Logistics Management, 23(3), 313-339. https:// doi.org/10.1108/09574091211289200

Gölgeci, I. and Kuivalainen, O. (2019). Does social capital matter for supply chain resilience? The role of absorptive capacity and marketing-supply chain management alignment. Industrial Marketing Management, 84, 63-74. https://doi.org/10.1016/ j.indmarman.2019.05.006

Hak, T., Kovanda, J. and Weinzettel, J. (2012). A method to assess the relevance of sustainability indicators, application to the indicator set of the Czech Republic's sustainable development strategy. Ecological Indicators, 17(1), 46-57. https:// doi.org/10.1016/j.ecolind.2011.04.034

Hallavo, V. (2015). Superior performance through supply chain fit, a synthesis. Supply Chain Management, International Journal, 20(1), 71-82. https://doi.org/10.1108/SCM-05-2014-0167

Hamel, G. and Välikangas, L. (2003). The quest for resilience. Harvard Business Review. September, p. 52-64.

Hendricks, K. (2005). A relationship between supply chain glitches and operating performance. Management Science, 51(5), 695-711. https:// doi.org/10.1287/mnsc. 1040.0353

Ireland, R. and Bruce, R. (2002). CPFR, Only the Beginning of Collaboration. Supply Chain Management. September/October 2020, p. 80-88

Ivanov, D., Sokolov, B. and Dolgui, A. (2014). The Ripple effect in supply chains, 'efficiency flexibilityresilience' trade-off in disruption management. International Journal of Production Research, 52(7), 2154-2172. doi.org/10.1080/00207543.2013.858836

Jahre, M. and Fabbe-Costes, N. (2015). How standards and modularity can improve humanitarian supply chain responsiveness, the case of emergency response units. Journal of Humanitarian Logistics and Supply Chain Management, 5(3), 348-386. https://doi.org/10.1108/JHLSCM-06-2015-0026

Jüttner, U. and Maklan, S. (2011). Supply chain resilience in the global financial crisis, an empirical study. Supply Chain Management, An International Journal, 16(4), 246-259. https:// doi.org/10.1108/13598541111139062

Kleindorfer, P.R. and Saad, G.H. (2005). Managing disruption risks in supply chains. Production and Operations Management, 14(1), 53-68. https:// doi.org/10.1111/j.1937-5956.2005.tb00009.x

Kurniawan, R., Zailani, S.H., Iranmanesh, M. and Rajagopal, P. (2017). The effects of vulnerability mitigation strategies on supply chain effectiveness, risk culture as moderator. Supply Chain Management, International Journal, 22(1), 1-15. https://doi.org/10.1108/SCM-12-2015-0482

Leat, P. and Revoredo-Giha, C. (2013). Risk and Resilience in Agri-Food Supply Chains, The Case of the ASDA Porklink Supply Chain in Scotland. Supply Chain Management, An International Journal, 18(2), 219-213. https:// doi.org/10.1108/13598541311318845

Lin, C.-T., Chiu, H. and Chu, P.-Y. (2006). Agility index in the supply chain. International Journal of Production Economics, 100(2), 285-299. https:// doi.org/10.1016/j.ijpe.2004.11.013

Manning, L. and Baines, R.N. (2004). Globalization, a study of the poultry meat supply chain. British Food Journal, 106(10), 819-836. https:// doi.org/10.1108/00070700410561414

Manning, L. and Soon, J.M. (2016). Building Strategic Resilience in The Food Supply Chain. British Food Journal, 118(6), 1477-1493. https://doi.org/10.1108/ BFJ-10-2015-0350

Manuj, I. and Mentzer, J.T. (2008). Global supply chain risk management strategies. International Journal of Physical Distribution and Logistics Management, 38 (3), 192-223. https:// doi.org/10.1108/09600030810866986

Mensah, P., Merkuryev, Y., Klavins, E. and Manak, S. (2017). Supply Chain Risks Analysis of a Logging Company, Conceptual Model. Journal of Procedia Computer Science, 104(207), 313-320. https:// doi.org/10.1016/j.procs.2017.01.140

Mikkola, J.H. and Skjøtt-Larsen, T. (2006). Implication for New Product Development and Supply Chain Management. European Business Review, 18(3), 214 -230. https://doi.org/10.1108/09555340610663737

Mintzberg, H. (1978). Patterns in strategy formation. Management Science, 24(9), 934-948. https:// doi.org/10.1287/mnsc.24.9.934

Morecroft, M.D., Crick, H.Q.P., Duffield, S.J. and Macgregor, N.A. (2012). Resilience to Climate Change, Translating Principles into Practice. Journal of Applied Ecology, 39(1), 547-551. https:// doi.org/10.1111/j.1365-2664.2012.02136.x

Mustaniroh, S.A., Mey, W. and Santoso, I. (2017). Risk Minimization Strategy for Apple Dodol Supply Chain with Analytical Hierarchy Process Approach (Case Study In SMEs Brosem, Batu City, East Java). International Journal of Social and Local Economic Governance (IJLEG), 3(2), 75-81

Muthuri, J., Moon, J. and Matten, D. (2006). Employee volunteering and the creation of social capital. 
Research Paper Series No. 34, Nottingham, United Kingdom: International Center for Corporate Social Responsibility.

Nuriyanto, N., Santoso, I., Soemarno, S. and Lestari, E.R. (2020). Identification of activities of the supply chain management of small and medium-sized enterprise meat chicken producers in Pasuruan district, Indonesia. Food Research, 4(6), 1954-1961. https://doi.org/10.26656/fr.2017.4(6).182

Pettit, T.J., Fiksel, J. and Croxton, K.L. (2010). Ensuring supply chain resilience, development of a conceptual framework. Journal of Business Logistics, 31(1), 121. https://doi.org/10.1002/j.21581592.2010.tb00125.x

Ponomarov, S.Y. and Holcomb, M.C. (2009). Understanding the concept of supply chain resilience. The International Journal of Logistics Management, 20(1), 124-143. https:// doi.org/10.1108/09574090910954873

Radosevic, M., Pasula, M., Berber, N., Neskovic, N. and Nerandzic, B. (2013). Reengineering of Supply Chain Processes in Production Systems - A Case Study. Engineering Economics, 24(1), 71-80. https:// doi.org/10.5755/j01.ee.24.1.2544

Rahmatin, N., Santoso, I., Christina, I., Sutik, R. and Shinta, W. (2018). Integration of the Fuzzy Failure Mode and Effect Analysis (Fuzzy FMEA) and The Analytical Network Process (ANP) in Marketing Risk Analysis and Mitigation. International Journal of Technology, 9(4), 809-818. https:// doi.org/10.14716/ijtech.v9i4.2197

Rice, J.B. and Caniato, F. (2003). Building a secure and resilient supply network. Supply Chain Management Review, 7(5), 22-30.

Roh, J., Hong, P. and Min, H. (2014). Implementation of a responsive supply chain strategy in global complexity, the case of manufacturing firms. International Journal of Production Economics, 147 (Part B), 198-210. https://doi.org/10.1016/ j.ijpe.2013.04.013

Saglam, Y.C., Çankaya, S.Y. and Zesen, B. (2020). Proactive Risk Mitigation Strategies and Supply Chain Risk Management Performance, an Empirical Analysis for Manufacturing Firms in Turkey. Journal of Manufacturing Technology Management. https://doi.org/10.1108/JMTM-08-2019-0299

Santoso, I., Sa'adah, M., Eva, N.S., Puspa, A.I.P. and Chintya, R.A. (2018). The Integration of MAFMA and AHP Methods for Analysis and Risk Mitigation of Pasteurized Milk Production. Journal Engineering Technology Science, 50(5), 670-683. https:// doi.org/10.5614/j.eng.technol.sci.2018.50.5.6
Sezen, B. (2008). Relative effects of design, integration and information sharing on supply chain performance. Supply Chain Management, International Journal, 13(3), 233-240. https:// doi.org/10.1108/13598540810871271

Shahzad, B. and Safvi, S.A. (2010). Risk Mitigation and Management Scheme Based on Risk Priority. Global Journal of Computer Science and Technology, 10(4), 108-113.

Sheffi, Y. (2001). Supply chain management under the threat of international terrorism. International Journal of Logistics Management, 12(2), 1-11. https://doi.org/10.1108/09574090110806262

Sheffi, Y. and Rice, J.B. (2005). A supply chain view of the enterprise resilient. MIT Sloan Management Review, 47(1), 41-48.

Sreedevi, R. and Haritha, S. (2017). Uncertainty and Supply Chain Risk, The Moderating Role of Supply Chain Flexibility in Risk Mitigation. International Journal of Production Economic, 193, 332-342. https://doi.org/10.1016/j.ijpe.2017.07.024

Stevenson, M. and Spring, M. (2007). Flexibility from a supply chain perspective, definition and review. International Journal Operation Production Management, 27(7), 685-713. https:// doi.org/10.1108/01443570710756956

Tang, C.S. (2006). Robust strategies for mitigating supply chain disruptions. International Journal of Logistics, Research and Applications, 9(1), 33-45. https://doi.org/10.1080/13675560500405584

Tukamuhabwa, R.B., Stevenson, M., Busby, J. and Zorzini, M. (2015). Supply chain resilience, definition, review and theoretical foundations for further study. International Journal of Production Research, 53(18), 5592-5623. https:// doi.org/10.1080/00207543.2015.1037934

Välikangas, L.A. and Romme, G.L. (2012). Building resilience capabilities at 'Big Brown Box'. Strategy and Leadership, 40(4), 43-45. https:// doi.org/10.1108/10878571211242948

Vickery, S.N., Calantone, R. and Droge, C. (1999). Supply chain flexibility, an empirical study. Journal of Supply Chain Management, 35(2), 16-24. https:// doi.org/10.1111/j.1745-493X.1999.tb00058.x

Wahyudin, N.E. and Santoso, I. (2016). Modeling of Risk Management for Product Development of Yogurt Drink Using the House of Risk (HOR) Method. The Asian Journal of Technology Management, 9(2), 98-108. https://doi.org/10.12695/ ajtm.2016.9.2.4

Wieland, A. and Wallenburg, C.M. (2012). Dealing with supply chain risks, Linking risk management 
Practices and Strategies to Performance. International Journal of Physical Distribution and Logistics Management, 42(10), 887-905. https:// doi.org/10.1108/09600031211281411

Wieland, A. and Wallenburg, C.M. (2013). The Influence of Relational Competencies on Supply Chain Resilience, A Relational View. International Journal of Physical Distribution and Logistics Management, 43(4), 300-320. https:// doi.org/10.1108/IJPDLM-08-2012-0243 